\title{
Methodology and calculation model for recycling of composite construction products
}

\author{
Victor Vladimirov ${ }^{1, *}$ and Ioan Bica ${ }^{1}$ \\ ${ }^{1}$ UTCB Technical University of Civil Engineering Bucharest, Hydrotechnical Faculty, Hydraulic and Environment Protection \\ Department, 124 Lacul Tei Blv., Bucharest, Romania
}

\begin{abstract}
The circular economy development has increased awareness on how construction products are treated at the end-of-life stage $(\mathrm{EoL})$. With a growing recognition of the finite nature of primary resources, manufacturing processes are being shifted from the traditional take-make-dispose approach to a greater holistic practice, where valuable and/or scarce substances are recovered at the end of a product's life. Life Cycle Assessment (LCA) is gaining wider attractiveness, as assessment of environmental impacts constitutes an effective quantitative decision tool to identifying sustainable solutions. At the same time, existing guidelines, technical specifications and methods for LCA assessment at EoL are rather heterogeneous regarding modelling and calculation of related secondary material and energy streams. For construction products, category rules for Environmental Product Declarations (EPD) according to EN 15804 (issued through the European Committee for Standardization) and the Product Environmental Footprint (PEF) (developed by the European Commission) currently represent the most advanced methodological references. The study presents the methodological approach per EN 15804, describing the benefits and loads beyond the typical disposal stage. Thus, the environmental impacts of a construction element can be credited in accord to its material and energetic recycling potential. An applied model is realized for water pipes made of composite material. The calculation is exemplified and comparative results of allocation scenarios per EN 15804 and PEF are discussed, demonstrating correlations between the normative requirements and their application. The results support further identification, assessment and ranking of recycling alternatives (i.e. mechanical, thermal, chemical).
\end{abstract}

\section{Introduction}

Modelling the end-of-life (EoL) of products stands amongst the most debated themes in LCA today [1]. This topic has been researched since the earlier development of LCA but the proposed approaches vary considerably, leading in many cases to substantially different results [2]. Currently existing guidelines, technical specifications and methods for environmental assessment of products (i.e. carbon foot-printing, Product Category Rules per EN 15804 or the Product Environmental Footprint PEF methodologies) adopted heterogeneous approaches. In fact, efforts to determine a coherent calculation methodology are relatively recent. In 2010 the LCA guide realized with support of the European Commission (the „ILCD Handbook”) defined guiding principles for the EoL approach, without establishing a calculation formula.

The PEF methodology (also developed by the European Commission) put special attention to an appropriate and reproducible EoL modelling starting with 2013. In this context, a unifying approach (called "the integrated formula") based on the "ILCD Handbook" and initiated in 2010 was anew put into light in 2014 by the
Commission's efforts to test and encourage further EoL assessments $[2,3,4]$. A PEF pilot project for construction products (for plastic and metal pipes) further elaborated on the formula for this specific application in the 20142016 period [5]. In parallel, the first version of EN 15804 for construction products appeared in 2012 while the EoL formula for product categories (i.e. for plastic pipes, prEN 16903) was issued four years later, in 2016.

This paper presents the methodological approach primarily per EN 15804 and prEN 16903, describing the benefits and loads beyond the typical disposal stage. The calculation is applied on pipes made of a composite material (glass-fibre reinforced polyester GRP). Choosing GRP as a pipe material is a further development to existing research, which focuses on plastic (i.e. PVC, PE) or metal (i.e. steel, aluminium) materials. As per EN 15804 (respectively prEN 16903) the EoL-recycling is considered as an optional extension of the model, called "Module D". This module covers the reutilisation, recuperation and recycling potential of products, describing the benefits and loads beyond the typical

\footnotetext{
$\overline{{ }^{*} \text { Corresponding author: victor.vladimirov@gmail.com }}$
} 
disposal stage (landfilling or incineration without energy recovery). The environmental impacts of a construction element can thus be credited in accord to its material and energetic recycling potential. Credits are given for avoiding future use of energy or primary material consumption through recycling [6]. The applied calculation model permits to further compare the results

\section{End-of-Life as per EN 15804 Module D}

According to European standards concerning the sustainability of construction works (i.e. EN 15804, EN 16903 and EN 15978), the life cycle information is organized along three major life cycle stages: (A) the product and construction process stage, (B) the use stage and $(\mathrm{C})$ the end-of-life stage $[6,7,8]$. The system boundary at the end of the life cycle is set where outputs have reached the "end-of-waste" state, leading to the recycled content approach ("Module D"), which is defined as an additional and optional life cycle stage. The module (D) thus covers the benefits and loads beyond the product usual life cycle (cradle to grave) [9]. The LCA stages are depicted in Fig. 1 below.

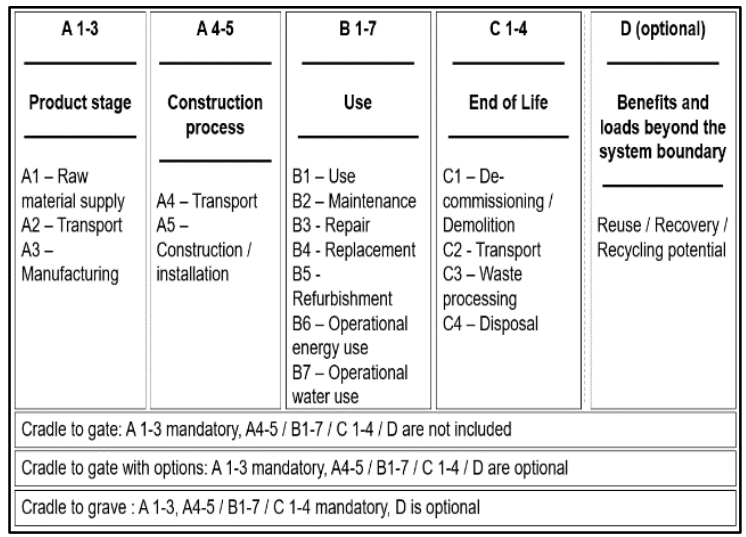

Fig. 1. Life cycle stages, source: EN 15804 [6].

The end-of-life stage includes modules C1 (deconstruction, demolition), C2 (Transport), C3 (waste processing) and C4 (disposal). During the end-of-life stage of the product all output from dismantling, deconstruction, demolition, maintenance, repair, replacement or refurbishing processes as well as all debris and all remaining construction elements are at first considered to be waste. This output reaches the end-ofwaste state (for recycling, beyond the system boundaries) when it complies simultaneously with a series of criteria: (a) the recovered material, product or construction element is commonly used for specific purposes, (b) a market or demand is identified (e.g. a positive economic value exists), (c) the recovered material, product or construction element fulfils the technical requirements for the specific purposes and meets the existing legislation as well as standards applicable to products and (d) the use of the recovered material, product or construction element will not lead to overall adverse environmental or human health impacts. After having reached the "end-of-waste" state, further processing (i.e. shredding of pipes) may be necessary in order to replace primary materials or fuel between EN 15804 and PEF. This allows to identify correlations between the normative requirements and their application. The results support further identification, assessment and ranking of recycling alternatives (i.e. mechanical, thermal, chemical) for construction products generally and specifically for composite pipes.

input in another product system. Such processes are considered beyond the system boundary and are assigned to module D. Secondary material having left the system can be declared as substituting primary production in module $\mathrm{D}$, when it has reached functional equivalence of the substituted primary material [6, 10]. Loads (e.g. emissions) from waste disposal in module $\mathrm{C} 4$ are considered part of the product system under study, according to the "polluter pays principle". However, if this process generates energy such as heat and power from waste incineration, the potential benefits from utilisation of such energy in the next product system are assigned to module $\mathrm{D}$ [10].

It is important to mention that recycled content can be calculated at both the input or output side of the model. If a product at EoL is entirely or partly diverted from the typical waste processing approach (i.e. landfilling), additional secondary material is becoming available for other uses. The product system that uses this secondary material as recycled content therefore does not need to source primary material any more. The benefit can be credited to the model. Recycled content can also be an input for production. In this case there are further environmental benefits for the product. However, if a credit of avoided primary production can be given, a debit of primary production can be modelled as well on the input side of the model, depending on the recycled content [2]. For example, if a material that consists of $50 \%$ recycled materials is recycled, then only half of those materials are substituting the extraction and refinement of virgin materials, respectively only $50 \%$ of benefits may be considered in Module D [11]. Debits can also be derived as part of the Module D activities, as transformation processes beyond the system boundary in order to obtain the point of functional equivalence (for example, GRP waste may need to be shred, to be used for subsequent production).

A further methodological consideration for the definition of the model per EN 15804, ISO 14044 and EN 16903 standards refers to close loop and open loop product systems $[5,12,13]$. In open loop situations, the inherent properties of the recyclate differ from those of the primary material in a way that it is usable only in other product applications [2]. Open loop recycling may be determined also by economic reasons, such as availability and cost of recycling methods. Examples of open loop recycling for GRP recyclate from GRP pipes include use of the material 
for ceramic sinks, plastic foil, railway sleepers or concrete blocks) [14]. In open-loop cases, the recycling rate (RR) is an important factor. The recycling rate corresponds to the actual amount of material obtained from recycling with the amount of material theoretically available at the end of the life of a product, including material losses during use, collection, scrap-preparation and processing (i.e. shredding of GRP material) (secondary material is used at the output phase). In close loop situations, the relevant indicator is the recycled content (RC). Recycled content looks at how much recycled material is re-used in the manufacturing of the product (secondary material is used at the input phase) [11]. Example of close loop recycling: GRP recyclate from GRP pipes is used for GRP pipe manufacturing.

Another methodological aspect refers to the allocation options regarding the recycled content. One situation is described as "100:0" allocation of the recycled content, in which case the loads and benefits are allocated $100 \%$ for the recycled input material. In this case the recycled materials entering the product model do not bring any further effects (credit or debit), as these were already previously determined. For instance, if recycled resin is used on the input of the GRP pipe model, the dataset enters as is (as any of the other production materials) and is not further credited (the recycled resin would have usually a lower environmental impact). The opposite allocation "0:100" (avoided impact) allows crediting (and debiting) the model fully for using recycled material. For example, the final impacts of the GRP pipe would be lower if the credits of the saved input material are bigger

\section{Calculation principles}

For a product system the environmental impacts of a model can be calculated as the sum of environmental loads and benefits. Comparative comments as per allocation methods (EN 15804, PEF) are equally referenced $[2,11]$. These elements are presented in the synthesis table below.

Table 1. Environmental benefits and loads for a product system (i.e. GRP pipe).

\begin{tabular}{|c|c|c|}
\hline Loads / Debits & Benefits / Credit & Comments \\
\hline \multicolumn{3}{|c|}{ Input of primary material (virgin content) } \\
\hline $\begin{array}{l}\text { Resources } \\
\text { consumed / } \\
\text { emissions for the } \\
\text { acquisition of } \\
\text { virgin material, } \\
\text { per kg (cradle-to- } \\
\text { gate) x (1 - } \\
\text { recycled content } \\
\% \text { of the analysed } \\
\text { product*). } \\
\text { * i.e. secondary } \\
\text { material (that has } \\
\text { been recycled in a } \\
\text { previous system) }\end{array}$ & Not applicable & $\begin{array}{l}\text { PEF "50:50" } \\
\text { allocation: only } \\
50 \% \text { of the } \\
\text { recycled content } \\
\text { is considered } \\
\text { EN 15804 typical } \\
\text { "100:0" } \\
\text { allocation: as is } \\
\text { (according to } \\
\text { process dataset) } \\
\text { Module D } \\
\text { " } 0: 100 " \\
\text { allocation: as is } \\
\text { (close loop) }\end{array}$ \\
\hline
\end{tabular}

than the debits of the recycling process. The median choice is a "50:50" allocation of impacts and benefits [11]. For instance, calculation per EN 15804 without model D uses "100:0", Module D specifically uses „0:100”, while the PEF methodology uses the ,50:50" allocation approach.

Finally, a further significant particularity is that recycling processes often produce secondary materials that are different to some degree from the original material (i.e. lower tensile strength). Such changes indicate that the substitution of primary material by the secondary material is not 1 to 1 [2]. In this situation, a substitution factor of functional equivalence needs to be considered [2, 11]. A secondary material can be declared as substituting primary production only when it has reached functional equivalence of the substituted primary material [11]. However, it should be noted that the recycling potential is not always clear. For example, even producers have difficulties to determine the future use of their products, which makes it difficult to determine the product it would be substituting. Furthermore, a recycled material can have different recycling routes, thus can be substituting different virgin materials [15]. Even the substitution factor may be approached from different perspectives: yield (i.e. $1 \mathrm{~kg}$ steel scrap produces less than $1 \mathrm{~kg}$ secondary steel) or value correction factor (i.e. secondary plastic can only be used in lower grade applications, also called “downcycling") [11].

\begin{tabular}{|c|c|c|}
\hline \multicolumn{3}{|c|}{ Input secondary material (recycled content) } \\
\hline $\begin{array}{l}\text { Recycled content } \\
\text { RC }(\%) \mathbf{x} \\
\text { substitution factor } \\
\text { (yield) } \mathbf{x} \text { resources } \\
\text { consumed / } \\
\text { emissions for the } \\
\text { acquisition of the } \\
\text { virgin material } \\
\text { substituted by the } \\
\text { secondary material } \\
\text { that is used as } \\
\text { recycled content } \\
\text { for the analysed } \\
\text { product (cradle-to- } \\
\text { gate, per kg) }\end{array}$ & $\begin{array}{l}\text { Module D: RC } \\
(\%) \text { of the same } \\
\text { product } \mathbf{x} \text { yield } \mathbf{x} \\
\text { impacts } \\
\text { connected to the } \\
\text { recycling } \\
\text { processes from } \\
\text { beyond the } \\
\text { system boundary } \\
\text { (close loop, same } \\
\text { product, Er) }\end{array}$ & $\begin{array}{l}\text { PEF "50:50" } \\
\text { allocation: only } \\
50 \% \text { of the } \\
\text { recycled content } \\
\text { is considered } \\
\text { EN 15804 typical } \\
\text { "100:0" } \\
\text { allocation: as is } \\
\text { (according to } \\
\text { process dataset) } \\
\text { Module D } \\
\text { "0:100" } \\
\text { allocation: load } \\
\text { not included } \\
\text { (open loop), load } \\
\text { included (close } \\
\text { loop, same } \\
\text { product, Ev) }\end{array}$ \\
\hline \multicolumn{3}{|c|}{ Output recyclate (recyclability of the product) } \\
\hline $\begin{array}{l}\text { Recyclate RR (\%) } \\
\text { obtained from EoL } \\
\text { treatment of the } \\
\text { analysed product, } \\
\text { that can be used in } \\
\text { subsequent product } \\
\text { systems instead of }\end{array}$ & $\begin{array}{l}\text { Recyclate RR } \\
(\%) \text { obtained } \\
\text { from EoL } \\
\text { treatment of the } \\
\text { analysed product, } \\
\text { that can be used } \\
\text { in subsequent }\end{array}$ & $\begin{array}{l}\text { PEF " } 50: 50 " \\
\text { allocation: only } \\
50 \% \text { of the } \\
\text { obtained } \\
\text { recyclate is } \\
\text { considered }\end{array}$ \\
\hline
\end{tabular}




\begin{tabular}{|c|c|c|}
\hline $\begin{array}{l}\text { a virgin material } \\
\text { (of the same or } \\
\text { different type) } \\
\mathbf{x} \text { resources } \\
\text { consumed / } \\
\text { emissions for the } \\
\text { EoL treatment of } \\
\text { the analysed } \\
\text { product, including } \\
\text { collection, sorting, } \\
\text { transportation, } \\
\text { recycling processes } \\
\text { to the point of } \\
\text { equivalence, } \\
\text { Er'(gate-to-gate, } \\
\text { per kg) }\end{array}$ & $\begin{array}{l}\text { product systems } \\
\text { instead of a } \\
\text { virgin material } \\
\text { (of the same or } \\
\text { different type) } \mathbf{x} \\
\text { resources } \\
\text { consumed/emissi } \\
\text { ons for the } \\
\text { acquisition of the } \\
\text { virgin material } \\
\text { assumed to be } \\
\text { substituted by the } \\
\text { recyclate) } \\
\text { obtained from } \\
\text { EoL treatment of } \\
\text { the analysed } \\
\text { product, Ev' } \\
\text { (cradle-to-gate, } \\
\text { per kg) } \mathbf{x} \text { yield }\end{array}$ & $\begin{array}{l}\text { EN 15804 typical } \\
\text { "100:0" } \\
\text { allocation: not } \\
\text { included } \\
\text { Module D } \\
\text { "0:100" } \\
\text { allocation: as is }\end{array}$ \\
\hline \multicolumn{3}{|c|}{ Output recovered energy } \\
\hline $\begin{array}{l}\text { The proportion of } \\
\text { material in the } \\
\text { analysed product } \\
\text { that is used for } \\
\text { energy recovery } \\
\text { RR }(\%) \mathbf{x} \text { resources } \\
\text { consumed / } \\
\text { emissions to } \\
\text { operate the energy } \\
\text { recovery process, } \\
\text { including } \\
\text { transporting, } \\
\text { conditioning, } \\
\text { storage etc. of the } \\
\text { material or } \\
\text { product, EER } \\
\text { (gate-to-gate, per } \\
\text { kg) }\end{array}$ & $\begin{array}{l}\text { The proportion } \\
\text { of material in the } \\
\text { analysed product } \\
\text { that is used for } \\
\text { energy recovery } \\
(\%) \mathbf{x} \text { lower } \\
\text { heating value of } \\
\text { the material in } \\
\text { the EoL product } \\
\text { that is processed } \\
\text { for energy } \\
\text { recovery (MJ/kg) } \\
\text { LHV x efficiency } \\
\text { of the energy } \\
\text { recovery process } \\
\text { XER } \mathbf{x} \text { avoided } \\
\text { resources } \\
\text { consumed / } \\
\text { emissions for the } \\
\text { specific } \\
\text { substituted } \\
\text { primary energy } \\
\text { sources for heat } \\
\text { and electricity } \\
\text { ESE }\end{array}$ & $\begin{array}{l}\text { PEF "50:50" } \\
\text { allocation: only } \\
50 \% \text { of the } \\
\text { energetic loads } \\
\text { and benefits are } \\
\text { considered } \\
\text { EN 15804 typical } \\
\text { "100:0" } \\
\text { allocation: only } \\
\text { process loads } \\
\text { (according to } \\
\text { process dataset) } \\
\text { Module D } \\
\text { "0:100" } \\
\text { allocation: as is }\end{array}$ \\
\hline \multicolumn{3}{|c|}{ Disposal } \\
\hline $\begin{array}{l}\text { Resources } \\
\text { consumed / } \\
\text { emissions for } \\
\text { disposal of the } \\
\text { various waste } \\
\text { materials from the } \\
\text { EoL product that } \\
\text { are obtained due to } \\
\text { direct landfilling, } \\
\text { reject, wastes } \\
\text { generate during } \\
\text { recycling or energy } \\
\text { recovery processes } \\
\text { (e.g. ashes), } \\
\text { including } \\
\text { transporting, } \\
\text { conditioning, } \\
\text { storage etc. of the } \\
\text { material or product }\end{array}$ & Not applicable & $\begin{array}{l}\text { PEF " } 50: 50 " \\
\text { allocation: only } \\
50 \% \text { of the } \\
\text { recyclate / } \\
\text { energy recovery } \\
\text { potential are } \\
\text { considered } \\
\text { EN 15804 typical } \\
\text { "100:0" } \\
\text { allocation: as is } \\
\text { (according to } \\
\text { process dataset) } \\
\text { Module D } \\
\text { "0:100" } \\
\text { allocation: }\end{array}$ \\
\hline
\end{tabular}

\begin{tabular}{|c|c|}
\hline $\begin{array}{l}\text { (gate-to-gate, per } \\
\mathrm{kg}) \mathbf{x}(1-\text { recyclate } \\
\text { obtained from EoL } \\
\text { treatment of the } \\
\text { analysed product } \% \\
\text { - the proportion of } \\
\text { material in the } \\
\text { analysed product } \\
\text { that is used for } \\
\text { energy recovery \%) }\end{array}$ & $\begin{array}{l}\text { disposal not part } \\
\text { of module D }\end{array}$ \\
\hline
\end{tabular}

The Module D (beyond system boundary) calculation is performed by adding impacts related to the recycling or recovery process from beyond the system boundary (up to the functional equivalence) and subtracting impacts resulting from the avoided production from primary resources, while applying a value-correction factor to reflect the differences in functional equivalence $[2,8,11]$.

The formula for Module D for the same product can be calculated as:

Module D net benefit impact indicator $=$ Yield * Amount * $\left[R R *\left(E v^{\prime}-E r^{\prime}\right)-R C *(E v-E r)+E E R\right.$ $-E S E * L H V * X E R]$

- $\quad \mathrm{RR}=$ Recycling rate at the end-of-life (EoL stage)

- $\mathrm{Ev}^{\prime}$ = Impacts of substituted virgin material production (EoL stage) (credit)

- $\mathrm{Er}^{\prime}=$ Impacts connected to the recycling processes from beyond the system boundary (after the end-of waste state up to the point of functional equivalence)

- $\quad \mathrm{RC}=$ Recycled content (product stage)

- $\mathrm{Ev}=$ Impacts of virgin material production (product stage)

- $\quad \mathrm{Er}=$ Impacts connected to the recycling processes from beyond the system boundary of the life cycle that generated the waste flow (after the end-of waste state)

- $\quad \mathrm{EER}=$ Resources consumed/emissions to operate the energy recovery process, including transporting, conditioning, storage etc. of the material or product

- $\quad \mathrm{ESE}=$ Avoided resources consumed/emissions for the specific substituted primary energy sources

- $\quad \mathrm{LHV}=$ Lower heating value of the material in the EoL product that is processed for energy recovery

- $\quad \mathrm{XER}=$ The efficiency of the energy recovery process (i.e. incineration with energy recovery

Within a classical model, the pipes are produced, used and then disposed of. If recycling is realized (i.e. into ceramic sink), then the recycling process to the point of substitution (shredding, outside system boundaries) becomes part of the model and the environmental impacts are added $(+$ debit) to the original model. The recycling process is the point of functional equivalence, where substitution of primary material takes place. Further processes such as the production of ceramic sinks is no longer included in the model. However, the "saved" impacts through 
recycling raw materials for sink production are included in the model as benefits and thus deducted from the environmental impacts (- credit).

\section{Application of EN 15804 Module D for construction products}

The applied model for a construction product is a GRP pipe. This product is typically used for water supply, drainage and sewerage. The declared unit is one-meter GRP pipe with a nominal diameter (DN) $1000 \mathrm{~mm}$, pressure class one PN 1 and a nominal stiffness (SN) 10000. The various environmental indicators for the pipes are included in the table below.

Table 2. LCA indicators for a GRP pipe DN $1000 \mathrm{~mm}$, PN1, per kg [14].

\begin{tabular}{|c|c|c|}
\hline Indicator & Value & Unit \\
\hline non-hazardous waste & $9,18 \mathrm{E}-02$ & $\mathrm{~kg}$ \\
\hline acidification potential & $3,35 \mathrm{E}-03$ & $\mathrm{~kg} \mathrm{SO}-\mathrm{Eq}$ \\
\hline GWP 100a & $1,09 \mathrm{E}+00$ & $\mathrm{~kg} \mathrm{CO}-\mathrm{Eq}$ \\
\hline eutrophication potential & $9,17 \mathrm{E}-04$ & $\mathrm{~kg} \mathrm{PO}-\mathrm{Eq}$ \\
\hline low NOx POCP & $1,32 \mathrm{E}-04$ & $\mathrm{~kg}$ ethylene \\
\hline $\begin{array}{c}\text { high NOx POCP } \\
\text { depletion of abiotic } \\
\text { resources }\end{array}$ & $2,05 \mathrm{E}-04$ & $\mathrm{~kg}$ ethylene \\
\hline $\begin{array}{c}\text { total renewable energy } \\
\text { total non-renewable energy }\end{array}$ & $2,17 \mathrm{E}+02 \mathrm{E}+00$ & $\mathrm{~kg}$ antimony \\
\hline
\end{tabular}

The assumptions for the calculation scenario (i.e. recycling rate, recycled content, transportation distances, etc.) are detailed in the following table.

Table 3. Assumptions for GRP pipe model calculation.

\begin{tabular}{|c|c|l|}
\hline Parameter & Unit & \multicolumn{1}{|c|}{ Remarks } \\
\hline Recycling rate (RR) & $95 \%$ & $\begin{array}{l}\text { A relatively high rate } \\
\text { is allocated; it is } \\
\text { considered that loses } \\
\text { though processing or } \\
\text { transport activities at } \\
\text { EoL are limited to } \\
5 \% \text { (this is the } \\
\text { indicative, potential } \\
\text { rate) }\end{array}$ \\
\hline Rest of waste to RR & $55 \%$ & $\begin{array}{l}\text { Landfill share, } \\
\text { Incineration share } \\
\text { [16] }\end{array}$ \\
\hline Recycled content (RC) & $5 \%$ & $\begin{array}{l}\text { A low level is } \\
\text { allocated due to } \\
\text { literature research } \\
\text { indicating difficulties } \\
\text { to re-integrate GRP } \\
\text { recyclate to the } \\
\text { original product. The } \\
\text { percent was set at } \\
\text { this level in order to } \\
\text { be able to determine }\end{array}$ \\
\hline
\end{tabular}

\begin{tabular}{|c|c|l|}
\hline & & $\begin{array}{l}\text { an impact in the } \\
\text { calculation [14] }\end{array}$ \\
\hline $\begin{array}{c}\text { Efficiency of the } \\
\text { incineration process }\end{array}$ & $90 \%$ & $\begin{array}{l}\text { Typical rate for } \\
\text { thermal process } \\
\text { efficiency }\end{array}$ \\
\hline $\begin{array}{c}\text { Yield of functional } \\
\text { equivalence }\end{array}$ & $85 \%$ & $\begin{array}{l}\text { Estimated, the } \\
\text { substitution of } \\
\text { primary material by } \\
\text { the secondary } \\
\text { material is not } 1 \text { to } 1\end{array}$ \\
\hline $\begin{array}{c}\text { Calorific value GRP } \\
\text { waste }\end{array}$ & 12 \\
\hline $\begin{array}{c}\text { Distance to the } \\
\text { incineration plant / } \\
\text { landfill / recycling plant }\end{array}$ & $300 \mathrm{~km}$ & $\begin{array}{l}\text { As per literature } \\
\text { research [17] }\end{array}$ \\
\hline $\begin{array}{l}\text { Estimated distance to } \\
\text { the incineration plant } \\
\text { / landfill / recycling } \\
\text { plant }\end{array}$ \\
\hline
\end{tabular}

Per EN 15804 system boundaries, the following are included in the calculation: product stage (A1 raw material supply, A2 transport, A3 manufacturing), end-of-life (C2 transport, C3 waste processing, $\mathrm{C} 4$ disposal) and benefits and loads beyond the system boundary (D). The calculation model is depicted in the figure below. It should be considered that the incineration of GRP results in production of ashes, which still need to be landfilled [18]. Furthermore, in order to be processed after the system boundaries, the GRP waste needs shredding to the point of functional equivalence, when it can replace other materials. These considerations are integrated in the figure below, thus providing more clarity on differences between waste activities (C1-C4) and recycling activities (D).

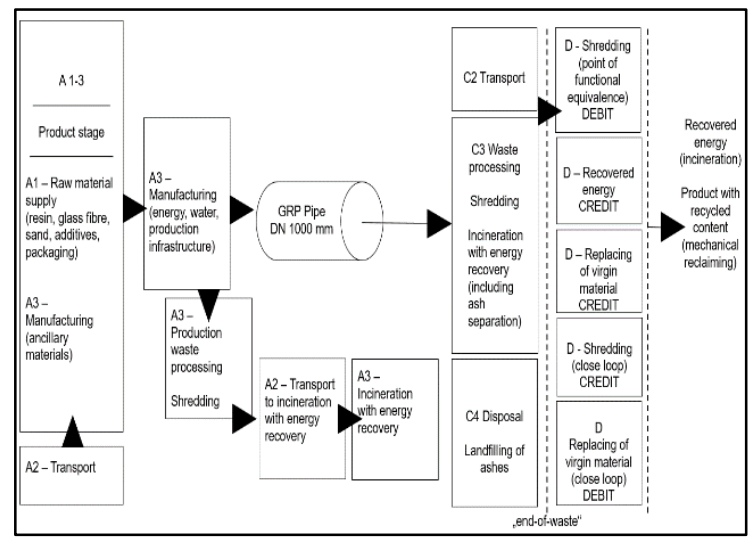

Fig. 2. GRP pipe model with system boundaries per EN 15804 .

The model is calculated with the Umberto NXT LCA software and the datasets are taken from the 
Ecoinvent version 2.2 database [19]. The model includes both open loop and close loop processing, with the recyclate being used as input for ceramic sinks and pipe production (mechanical recycling). The GRP recyclate replaces kaolin (for open loop) while the mix of the unsaturated polyester resin, glass fibre and sand is reduced on the pipe input side (for close loop).

\section{Results and conclusions}

Results for mechanical recycling of GRP waste to ceramic sink tend to be positive for the majority of impact indicators. Most benefit is obtained for eutrophication potential, depletion of abiotic resources, non-renewable energy and acidification potential. Indicators are presented in the figure below (values and percentage variation in reference with the LCA results in Table 2).

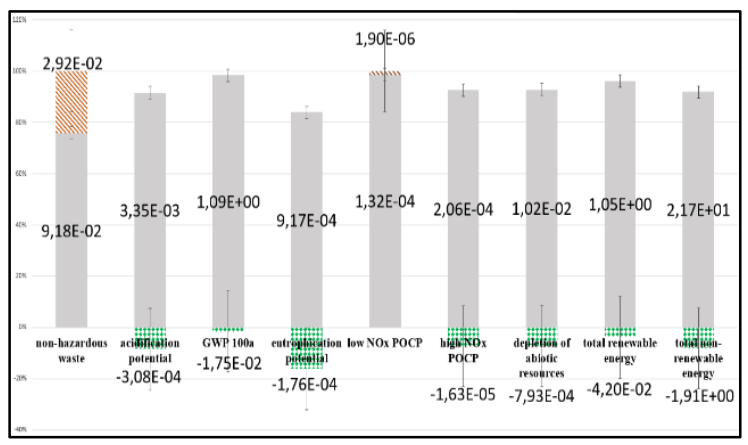

Fig. 3. Product level [emissions/kg], mechanical recycling open loop (ceramic sink) and close loop and incineration of waste with energy recovery, with Module D loads and benefits (0:100 allocation).

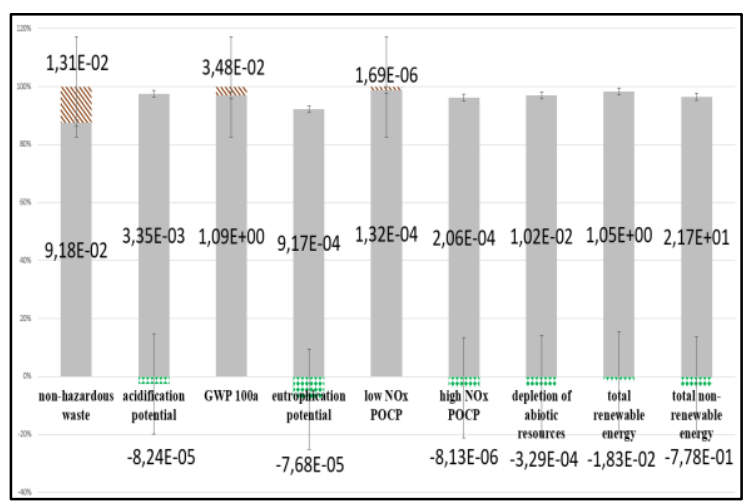

Fig. 4. Product level [emissions/kg], mechanical recycling open loop (ceramic sink) and close loop and incineration of waste with energy recovery, with Module D loads and benefits (50:50 PEF allocation).

Through application of Module D, credits were allocated for replacing kaolin and debits for shredding the pipe at EoL (open loop) as well as credits for shredding the pipe and debits for replacing virgin materials at pipe production input (close loop). Impacts were affected by calculation of close loop slightly. A higher recycled content may influence total results positively, depending on the impacts of the recycling to functional equivalence process. In case of the GRP product it is expected that this influence would be positive but moderate (the environmental impact of the recycling process is slightly higher than that of the recyclate).

The scenario is calculated a second time with a 50:50 allocation, as per PEF. The results are depicted in the figure below.

$50: 50$ allocation means that only $50 \%$ of the impacts of the recycled content and of the recyclate are considered for the input of primary and secondary material. For the disposal stage, equally only $50 \%$ of the recycled content and of the obtained recyclate are considered. In this approach, the allocated credits are reduced and this is visible in the total results (slightly increased environmental load for the atmospheric emissions and energy consumption), while the amount of generated waste decreases. This approach seems to be a more restraint but perhaps a more balanced one, considering the high variety of recycling situations on the market and the limited availability of supply-chain datasets in LCA analysis. Overall, however, there are no significant differences between the two calculated allocation methods.

Similar EoL models for pipes (inside the building) were performed for instance on the PEF pipe pilot project for plastic (polyethylene) or metal (stainless steel, aluminium). Defining a model for GRP as pipe material (composites) and for a large diameter is a contribution to existing research. Furthermore, the model can be used for comparative analysis for different waste treatment and recycling methods for the composite material. For example, the results support further identification, assessment and ranking of recycling alternatives (i.e. mechanical, thermal or chemical).

\section{References}

1. J. Reap, F. Roman, S. Duncan, B. Bras, Int. J. Life Cycle Assess., 13, 290-300 (2008)

2. M.A. Wolf, K. Chomkhamsri, The "Integrated formula" for modelling recycling, energy recovery and reuse, LCA White paper, Berlin (2014)

3. K. Allacker, F. Mathieux, S. Manfredi, N. Pelletier, C. De Camillis, F. Ardente, R. Pant, Resour. Conserv. Recycl., 88, 1-12 (2014)

4. JRC, European Commission, Manualul sistemului internațional de referință privind datele despre ciclul de viață (ILCD) - Linie directoare generală pentru Evaluarea Ciclului de viață - Ghid detaliat, Brussels (2010)

5. CE European Commission, Product Environmental Footprint - Category Rules (PEFCR) for hot and cold water supply piping systems in the building, v.3.1, Brussels (2016)

6. CEN, EN15804:2012, Sustenabilitatea lucrărilor de constructii - Declarații de mediu pentru produseReguli principale pentru categoria de produse de construcții, Brussels (2012) 
7. CEN, EN 15978:2011, Sustenabilitatea lucrărilor de construcții - Evaluarea performanței de mediu a construcțiilor - Metodă de calcul, Brussels (2011)

8. CEN, prEN 16903, Plastics piping systems Sustainability of construction works - Product Category Rules (PCR) for buried plastics piping systems, Brussels (2016)

9. L. Delem, J. Van Dessel, Relevance of the recycling potential (module D) in building LCA: A case study on the retrofitting of a house in Seraing, Sustainable Building Conference, Graz, (2013)

10. Austrian EPD-Platform, Product Category Rules for Building Related Products and Services for preparation of EPDs, v.11, Vienna (2016

11. L. Wastiels, End Of Life - Module $C$ and D, Workshop: EPD, The Current Debate and Challenges, Brussels (2015)

12. ISO 14044, 2006 Environmental Management-Life Cycle Assessment-Requirements and guidelines, Geneva (2006)

13. ISO/TR 14049, Managementul de mediu - Evaluarea ciclului de viață - Exemple de aplicații ISO 14041 la definiția scopului și domeniului de aplicare și analizei de inventar, Geneva (2000)

14. V. Vladimirov, I. Bica, Circular Economy: Recycling Glass Fibre Reinforced Composites (GRP) according to EN 15804 Module D (End-of-life) through applied LCA Scenarios, ARA, Bucharest (2017)

15. L. Wastiles, L. Delem, J. Van-Dessel, To module D or not to module D?, the relevance and difficulties of considering the recycling potential in building $L C A$, AVENIR, Brussels (2013)

16. A. DeSchryver, Fază pilot a amprentei de mediu UE, PEF-OEF_EOL Default Data, v1.2, Brussels (2017)

17. S. Job, Reinf. Plastics, 57, 15 (2013)

18. A. Yazdanbakhsh, L.C. Bank, Polym., 6, 1810-1826

(2014)

19. ifu-Hamburg, Umberto for LCA, Hamburg, (2017) 